\title{
APLIKASI ORDERING INTERIOR AND EXTERIOR RUMAH PADA CV. ALTRA PRATAMA BERBASIS ANDROID
}

\author{
Saleh Dwiyatno ${ }^{1}$, Edy Rakhmat ${ }^{2}$, Ayu Purnama Sari ${ }^{3}$, Zanuandry ${ }^{4}$ \\ 1,3,4 Universitas Serang Raya \\ Jl. Raya Serang Cilegon Drangong Taktakan Kota Serang Banten \\ ${ }^{2}$ Universitas Banten Jaya \\ Jl. Ciwaru II No. 73 Warung Pojok Kota Serang Banten \\ Email:salehdwiyatno@gmail.com ${ }^{1}$, edyrakhmat@unbaja.ac.id ${ }^{2}$, \\ ayupurnamasarifaliza@gmail.com ${ }^{3}$, zanuandry@gmail.com ${ }^{4}$
}

\begin{abstract}
This research was conducted at CV.Altra Pratama with the aim to design a system to help the CV.Altra Pratama in an effort to expand sales millionaires and facilitate consumers in purchasing. Previously they still used conventional methods or customers came directly to the store, so to make it easier in the transaction is made an application system ordering interior and exterior homes in CV.Altra Pratama, in order to maximize sales and marketing. In this study using an Android-based programming language and for terms of writing using the prototype method. This making uses Android Studio version 3.0.2 and Android SDK as API tools. Application made with java and XML programming languages.
\end{abstract}

Keywords: Ordering Interior And Exterior, Home, Prototype, Android

\section{PENDAHULUAN}

Di zaman yang sudah modern ini perkembangan teknologi semakin pesat hampir semua kebutuhan serta kegiatan manusia dapat di lakukan menggunakan teknologi yaitu internet. Penggunaan internet mempermudah semua kebutuhan serta kegiatan untuk berkomunikasi, berbisnis dan lainnya. Sektor bisnis merupakan sektor yang berpengaruh terkena dampak dari perkembangan teknologi melalu iteknologi dan telekomunikasi. Munculnya electronic commerce merupakan kemajuan dari sektor bisnis yang memanfaatkan perkembangan teknologi. Melalui e-commerce banyak memunculkan peluang bisnis dan kreativitas dalam membuka usaha baru menggunakan komputer atau gadget sebagai alat komunikasi, pemasaran, dan transaksi bisnis.

Electronic Commerce atau biasa di sebut penjualan online merupakan proses penjualan yang memanfaatkan teknologi internet dengan menggunakan komputer atau gadget sebagai alat untuk melakukan transaksi. Manfaat dari penggunaan $e$ - 
commerce memudahkan penjual untuk menawarkan barang yang dijual menggunakan teknologi internet melalui media iklan, sosial media dan lainya. Ecommerce juga memudahkan pembeli untuk memesan barang dengan menggunakan Aplikasi tanpa harus datang langsung ke lokasi penjual. Dengan adanya e-commerce di harapkan mampu mengimbangi persaingan bisnis di era globalisasi dengan system penjualan yang lebih baik dan modern.

"CV. Altra Pratama" merupakan perusahaan yang bergerak di bidang Interior dan Exterior Rumah. Lingkup usaha tersebut meliputi pemesanan interior, exterior, dan gambar rencana. CV. Altra Pratama berada di lokasi Kabupaten Lebak, berdiri sejak tahun 2016. Pemesanan interior dan exterior rumah yang dilakukan oleh konsumen saatini masih menggunakan sistem konvensional yaitu pembeli harus datang ke toko langsung untuk melakukan pemesanaan barang. Hal tersebut tidak efektif apabila jarak antara perusahaan dan pemesan berjauhan. Halini tentunya membutuhkan waktu dan biaya yang lebih besar. Dan juga sistem pemasaran pada CV. Altra Pratama hanya di lakukan di toko saja. Sehingga jangkauan produk hanya berada pada satu wilayah saja. Di karenakan era persaingan yang semakin ketat, dan masih kurangnya usaha penjualan interior dan eksterior rumah yang memanfaatkan e-commerce. Oleh karena itu CV. Altra Pratama membutuhkan Aplikasi untuk mengatasi kebutuhan konsumen yang tidak dapat datang langsung ke toko.

Berdasarkan permasalahan di atas dan semakin berkembangnya teknologi secara pesat, maka diperlukan suatu media yang dapat memandu dan memberikan informasi dengan cepat. Android adalah sistem operasi mobile yang akhir-akhir ini menjadi populer di kalangan smartphone. Android adalah sistem operasi berbasis open source sehingga pengguna bisa membuat aplikasi baru di dalamnya. Dalam hal ini peneliti ingin mencoba merancang suatu aplikasi yang dapat memberikaninformasi kepada masyarakat khususnya konsumen di CV. Altra Pratama tentang informasi produk yang diperlukan secara tepat yang dikemas melalui sebuah aplikasi mobile berbasis android. Berdasarkan hal tersebut, maka penulis mengangkat permasalahan ini dengan judul "Aplikasi Penjualain Online Pada CV.Altra Pratama Berbasis Android“. Dengan adanya penelitian ini di harapkan dapat membantu dan memudahkan konsumen dalam melakukan 
pemesanan barang dan memudahkan toko dalam memperluas jangkauan pemasaran produk.

Berdasarkan dari latar belakang masalah yang telah dibahas sebelumnya, maka identifikasi masalah yang ada dalam penelitian ini, adalah: pemasaran produk terbatas hanya di lakukan pada toko, sehingga jangkauan pemasaran masih kurang luas dan berakibat kurangnya daya saing toko dengan toko lainnya.

Berdasarkan Identifikasi masalah di atas maka perumusan masalah penelitian ini adalah bagaimana cara membuat Aplikasi Penjualain Online Pada CV.Altra Pratama Berbasis Android?.

\section{PEMECAHAN MASALAH}

Dalam menentukan permasalahan yang terjadi peneliti melakukan analisis sistem yang sedang berjalan dilakukan dengan mengevaluasi sistem yang ada serta untuk mengetahui proses kerja dan kegiatan yang berkaitan dengan proses penjualan guna menemukan hambatan-hambatan, kekurangan dan kebutuhankebutuhannya supaya dapat ditemukan solusi dari sistem yang sedang berjalan dan dapat ditentukan kebaikan-kebaikan sistem kedepannya. Analisis yang sedang berjalan bertujuan untuk mengetahui lebih jelas bagaimana cara kerja sistem yang menjadi objek penelitian dan masalah yang dihadapi sistem untuk dijadikan landasan usulan perancangan sistem. Seperti yang terlihat pada gambar 1.

Setelah melakukan analis system yang berjalan di temukan teknik penyelesaian masalah pada proses penjualan di CV.Altra Pratama yaitu :

1. Membangun aplikasi Penjualan online Interior and Exterior rumah yang akan digunakan oleh pihak konsumen berbasis android

2. Memasang aplikasi penjualan online interior and exterior sebagai media memudahkan konsumen dalam melakukan transaksi dan pelayanan. 


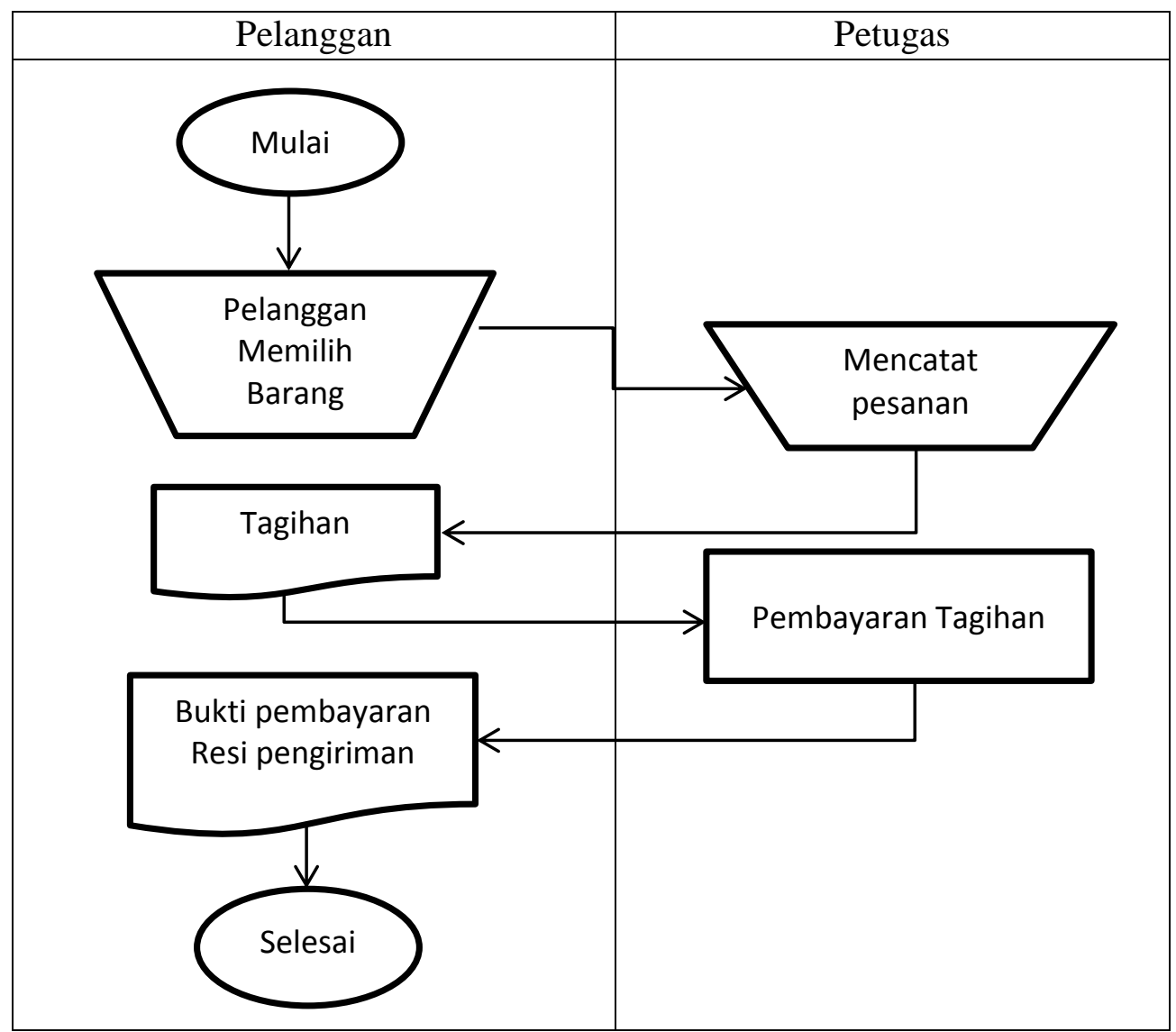

Gambar 1 Flowmap Gambaran Umum Objek Penelitian

\section{Analisisa Pengguna Sistem}

Pengguna yang akan menggunakan aplikasi yang akan digunakan ini terdiri dari dua yaitu admin dan konsumen.

Admin dan konsumen menggunakan aplikasi android, dengan asumsi dapat dilihat pada tabel 1 .

Table 1 Pengguna Sistem

\begin{tabular}{|l|l|l|}
\hline No & Pengguna & \multicolumn{1}{c|}{ Keterangan } \\
\hline 1. & Admin & $\begin{array}{l}\text { Sebagai pengguna aplikasi yang dapat menggunakan akses } \\
\text { lebih banyak dari pada konsumen atau pengguna android dan } \\
\text { sebagai pengelola system database pada aplikasi yang akan } \\
\text { digunakan }\end{array}$ \\
\hline 2. & Konsumen & $\begin{array}{l}\text { Sebagai pengguna aplikasi yang dapat menggunakan hak akses } \\
\text { terbatas yang hanya dapat memesan ke pihak CV.Altra } \\
\text { pratama. }\end{array}$ \\
\hline
\end{tabular}




\section{Analisa Kebutuhan Hardware}

Perangkat keras yang di butuhkan saat penelitian dapat dilihat pada tabel 2.

Tabel 2 Kebutuhan Hardware

\begin{tabular}{|c|l|l|l|}
\hline No & \multicolumn{1}{|c|}{$\begin{array}{c}\text { Nama } \\
\text { Perangkat }\end{array}$} & \multicolumn{1}{|c|}{ Spesifikasi } & \multicolumn{1}{c|}{ Fungsi } \\
\hline 1. & $\begin{array}{l}\text { Laptop / } \\
\text { kompuer PC }\end{array}$ & $\begin{array}{l}\text { Processor Core i3, } \\
\text { Memory(Ram) 4Gb,intel } \\
\text { graphic Hd,windows 10,500 } \\
\text { Gb free hardisk space }\end{array}$ & $\begin{array}{l}\text { untuk menyimpan file dan } \\
\text { melakukan pengkodean } \\
\text { aplikasi serta uji coba } \\
\text { aplikasi }\end{array}$ \\
\hline 2. & Handphone & $\begin{array}{l}\text { Oppo A37,Ram 2 Gb, internal } \\
\text { 16 Gb }\end{array}$ & Untuk instalasi aplikasi \\
\hline
\end{tabular}

\section{Analisa Kebutuhan Software}

Perangkat Lunak yang di butuhkan saat penelitian dapat dilihat pada tabel 3.

Tabel 3 Kebutuhan Software

\begin{tabular}{|l|l|l|l|}
\hline No & \multicolumn{1}{|c|}{ Aplikasi } & \multicolumn{1}{|c|}{ Spesifikasi } & \multicolumn{1}{c|}{ Fungsi } \\
\hline 1. & Android Studio & $\begin{array}{l}\text { Versi 3.1.3, Java, } \\
\text { XML }\end{array}$ & $\begin{array}{l}\text { Sebagai Alat untuk desain aplikasi } \\
\text { dan pengkodean aplikasi }\end{array}$ \\
\hline 2. & Sublime text 2 & $\begin{array}{l}\text { Versi 3.3, Plugin } \\
\text { Emet, Pyton 3.3 }\end{array}$ & Sebagai text editor \\
\hline 3. & Xampp & $\begin{array}{l}\text { PHP 7, Apache } \\
2.4\end{array}$ & $\begin{array}{l}\text { Sebagai web server bendiri } \\
\text { sendiri(localhost) }\end{array}$ \\
\hline 4. & Mozilla Firefox & $\begin{array}{l}\text { Firefox 61.0.1 } \\
\text { (64-bit) }\end{array}$ & Sebabai alat testing web \\
\hline
\end{tabular}

\section{Analisa Kebutuhan Arsitektur Pendukung}

Analisa arsitektur pendukung dapat dilihat pada gambar 2

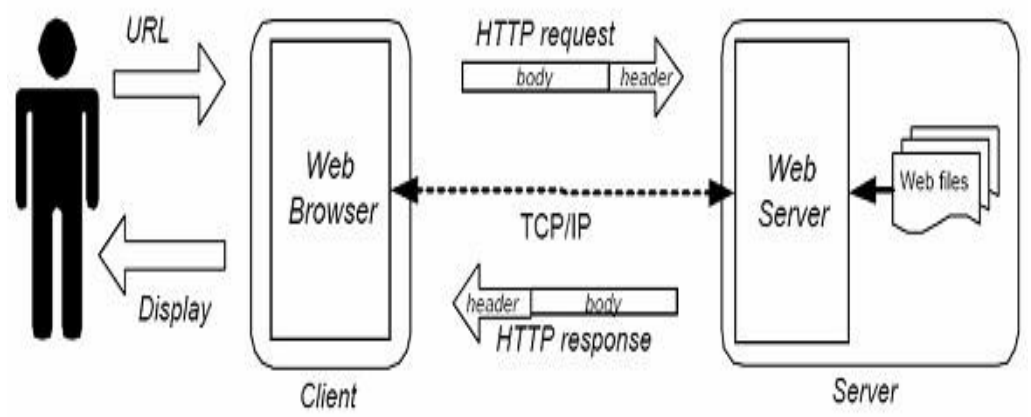

Gambar 2 Alur web service 
Tabel 4 Arsitektur Pendukung

\begin{tabular}{|c|c|c|l|}
\hline No & Arsitektur & Spesifikasi & \multicolumn{1}{c|}{ Fungsi } \\
\hline 1. & $\begin{array}{c}\text { Server hosting } \\
\text { dan domain }\end{array}$ & $\begin{array}{c}\text { Kapasitas 5 Gb } \\
\text { Bandwith } \\
\text { Unlimited }\end{array}$ & $\begin{array}{l}\text { Untuk menyimpan data aplikasi } \\
\text { web dan dapat di akses melaui } \\
\text { jaringan internet }\end{array}$ \\
\hline
\end{tabular}

\section{Metode Pengembangan Prototype}

Prototype Model adalah salah satu metode pengembangan perangkat lunak yang banyak digunakan. Dengan Metode model Prototyping ini pengembangan dan pelanggan dapat saling berinteraksi selama proses pembuatan sistem. Sering terjadi seorang pelanggan hanya mendefinisikan secara umum apa yang dibutuhkan, Pemrosesan dan data-data apa saja yang dibutuhkan. Sebaliknya disisi pengembang Kurang memperhatikan efesiensi Algoritma. Kemampuan sistem oprasi dan interface yang menghubungkan manusia dengan komputer.

\section{Perancangan Sistem}

Kebutuhan Fungsionalitas Sistem berupa Menu-menu yang ada di dalam aplikasi yang dapat di uraikan sebagai berikut:

1. Login. Fungsi menu login yaitu login sebagai admin dan konsumen, ketika login masuk ke menu utama admin, terdapat beberapa submenu seperti menu konfiramsi pesanan, dan menu update status pemesanan.

2. Home. Fungsi Menu home adalah menu tampilan awal saat setelah login dan di menu home ini pengguna bisa memilih item yang tersedia di menu katalog.

3. Status. Fungsi Menu status adalah menu tampilan ketika pengguna sudah melakukan pemilihan item barang pesanan maka pesanan pengguna akan ada di menu status untuk mengecek status pemesanan.

4. Konfirmasi. Fungsi Menu konfirmasi adalah menu tampilan konfirmasi pembayaran berupa struk transaksi dengan jumlah yang sesuai dengan pesanan.

5. News. Fungsi Menu news adalah menu tampilan berita dari pihak pembuat aplikasi.

6. MyProfil. Fungsi Menu myprofil adalah menu tampilan profil pengguna dan tombol sign out. 


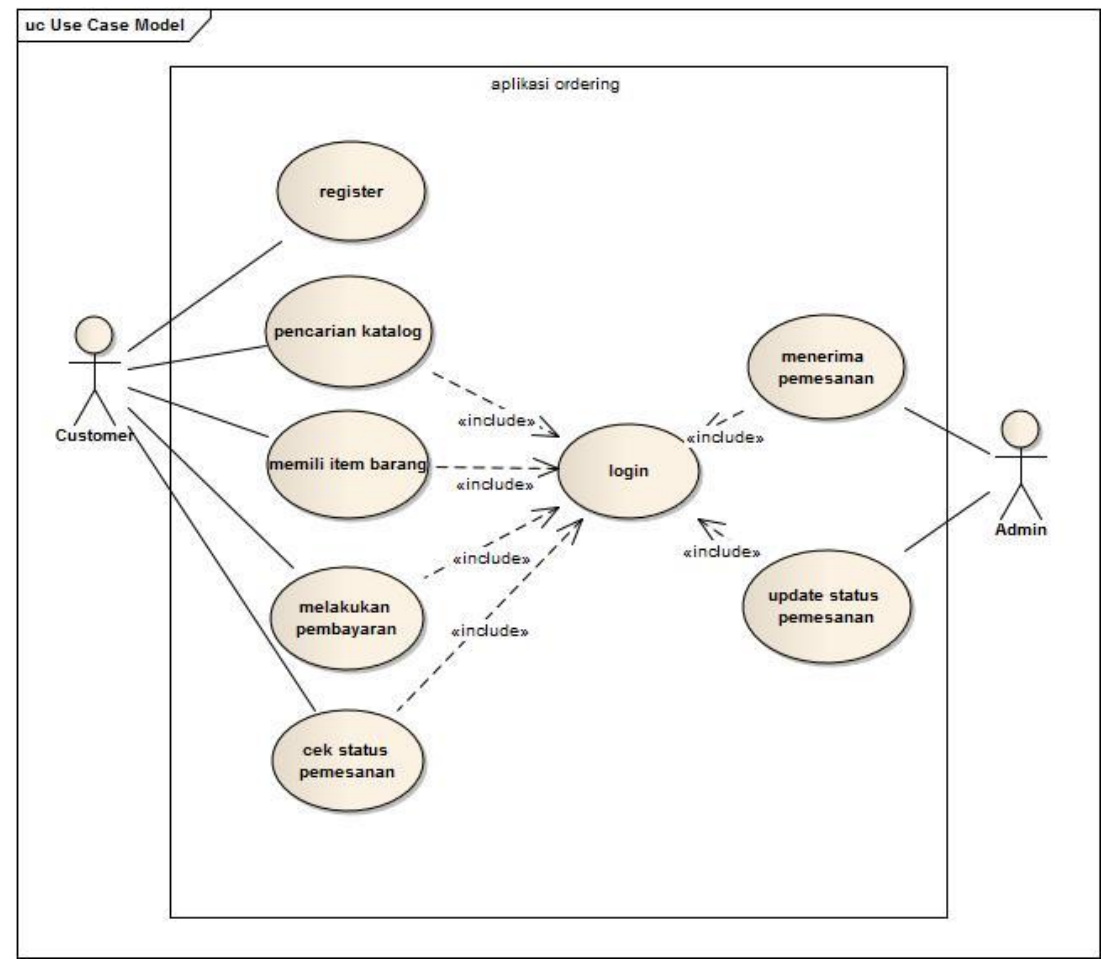

Gambar 3 Diagram Use case

Activity diagram menggambarkan alur kerja sebuah sistem dalam suatu proses berdasarkan Use Casediagram pada gambar 3, maka dapat digambarkan activity diagram seperti terlihat pada gambar 4 dan gambar 5 .

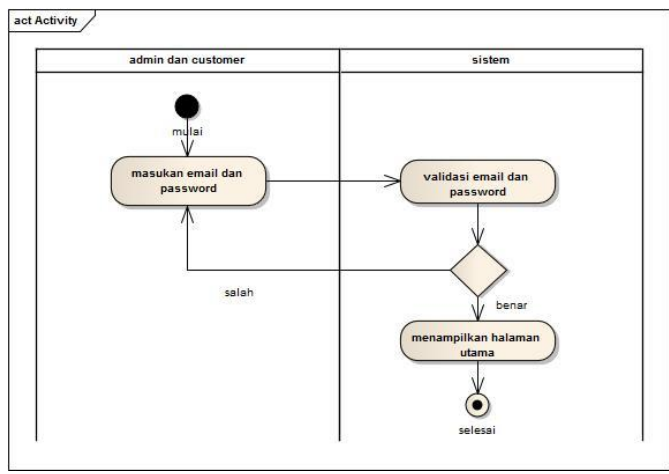

Activity diagram Login

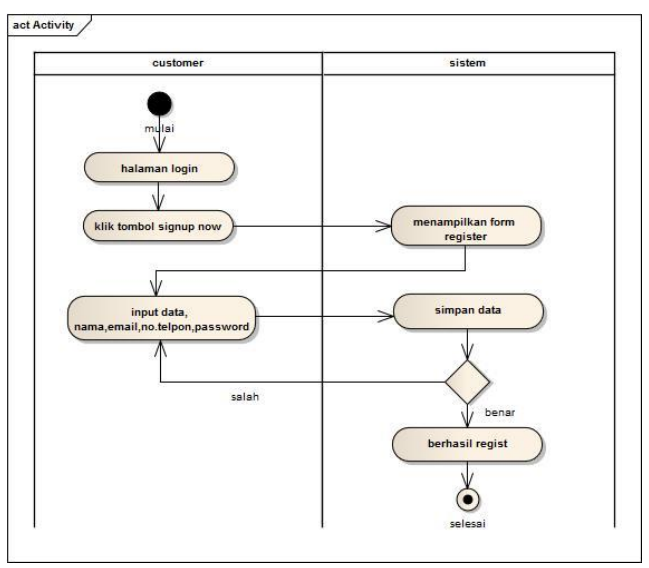

Activity diagram Registrasi

Gambar 4 Activity diagram 


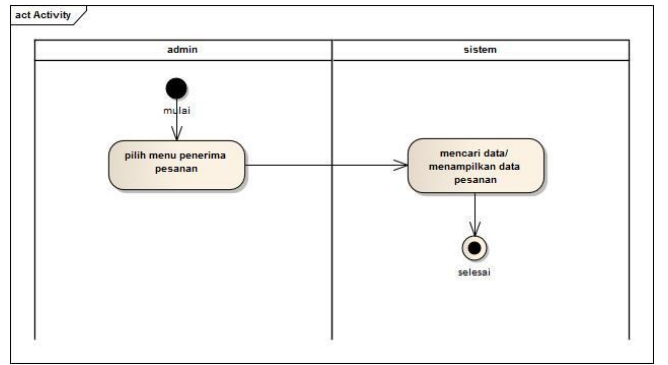

Activity diagram menerima pemesanan

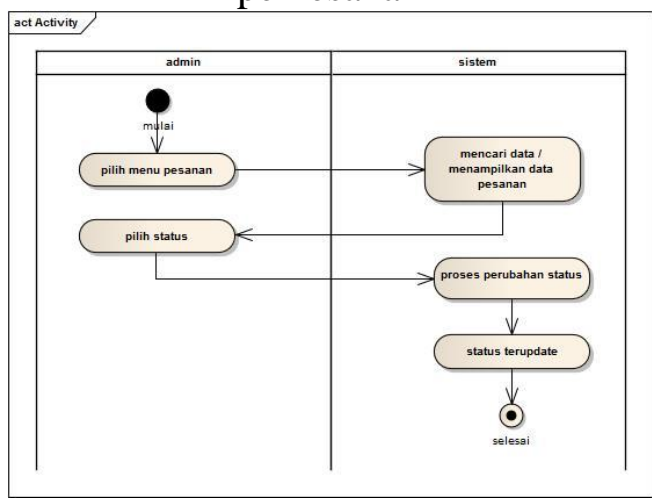

Activity diagram update status pemesanan

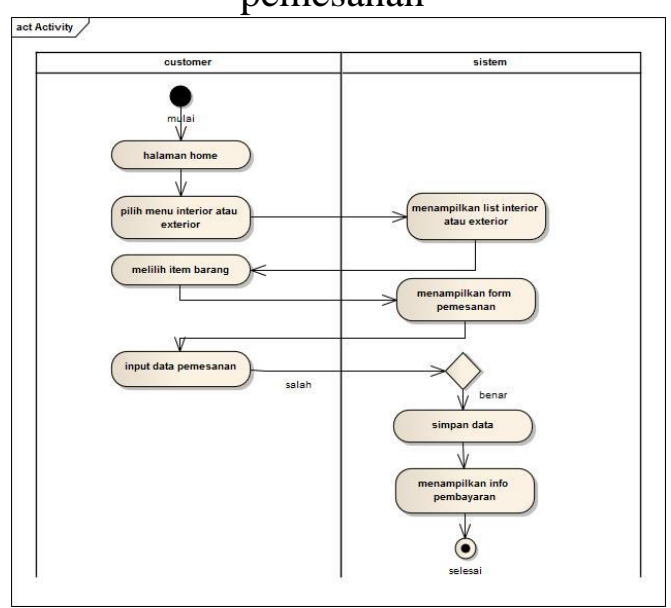

Activity diagram pembayaran

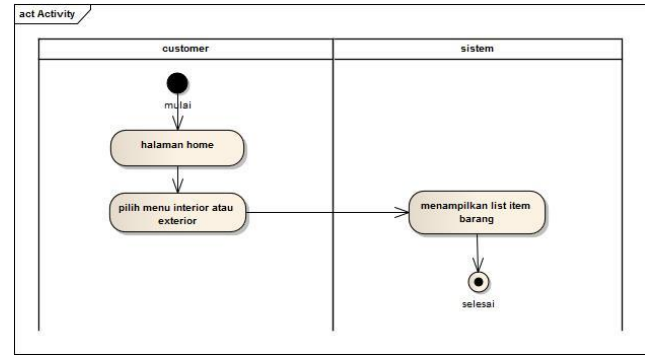

Activity diagram pencarian katalog

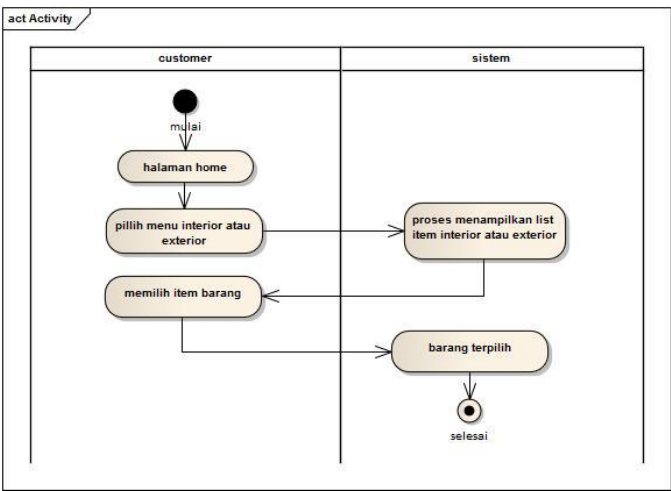

Activity diagram memilih item barang

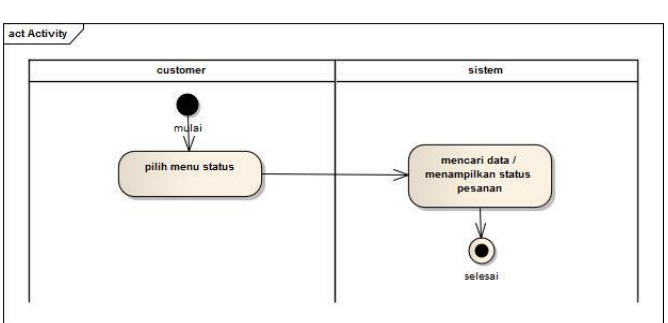

Activity diagram cek status pembayaran

Gambar 5 Activity diagram lanjutan 


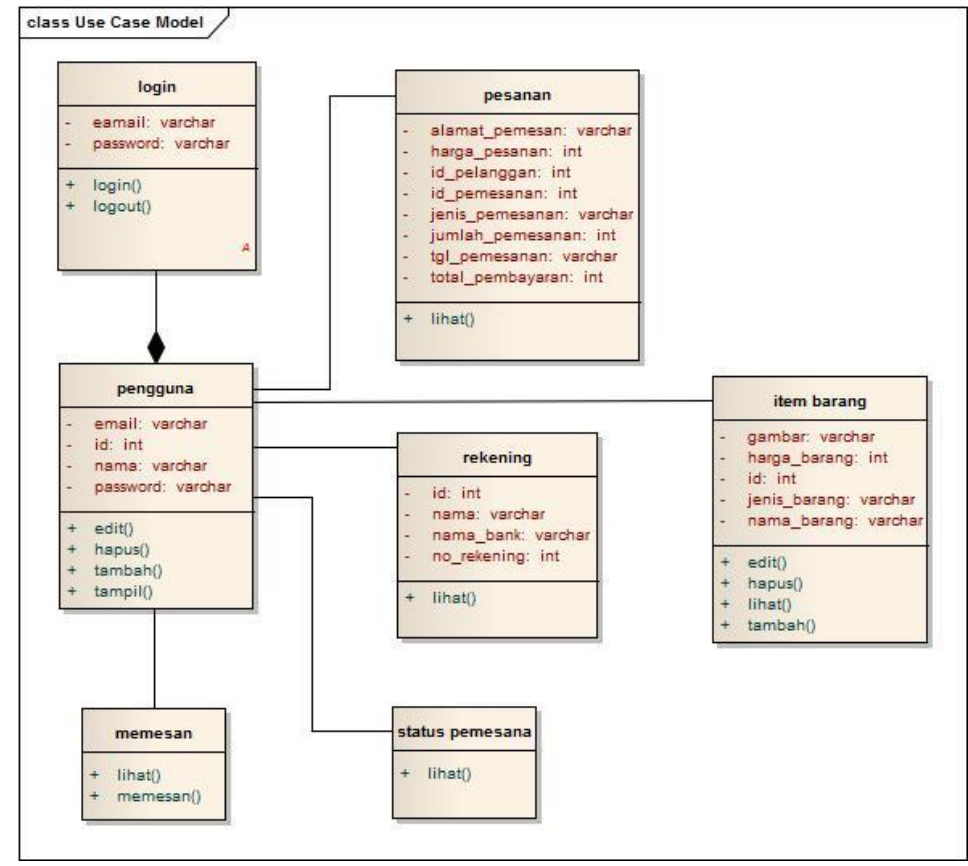

Gambar 6 Class Diagram
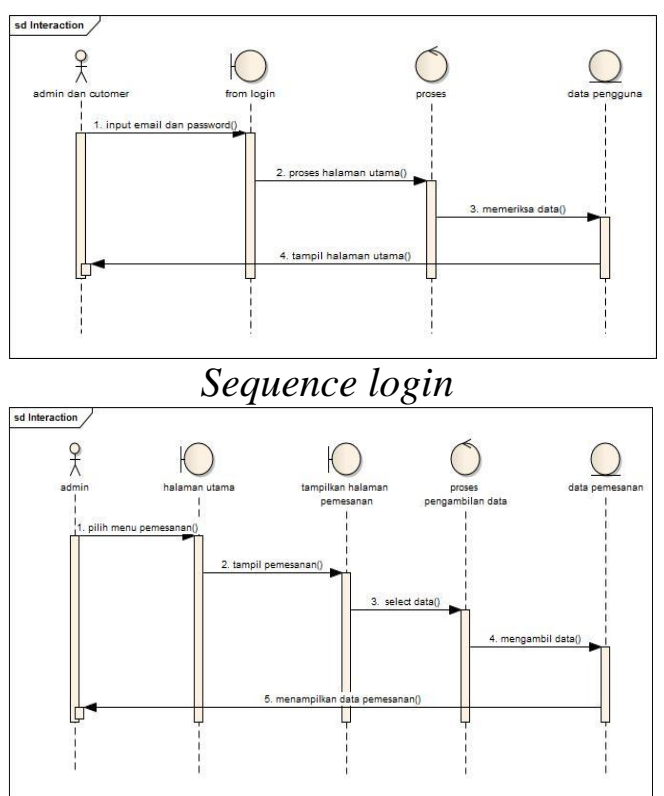

Sequence menerima pemesanan

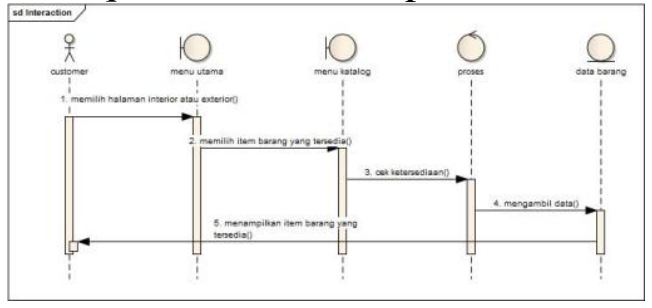

Sequence pencarian katalog

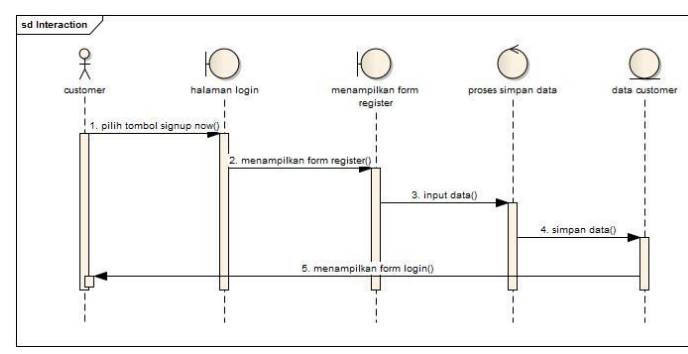

Sequence register

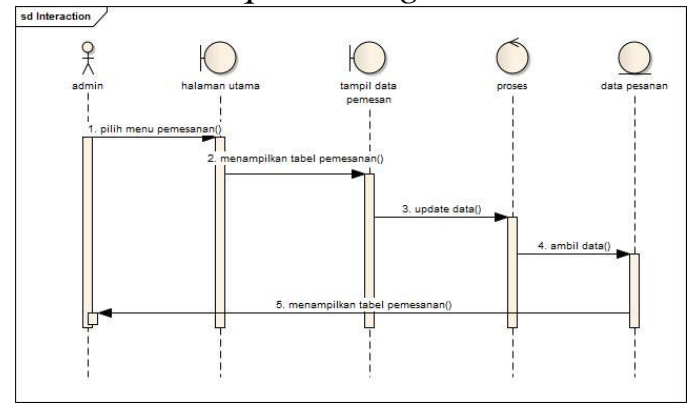

Sequence update status pemesanan

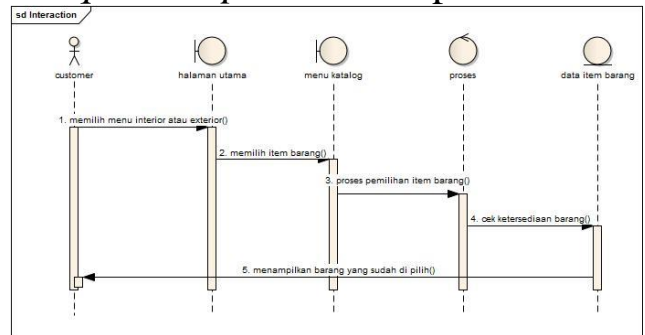

Sequence memilih item barang

Gambar 7 Sequence diagram 


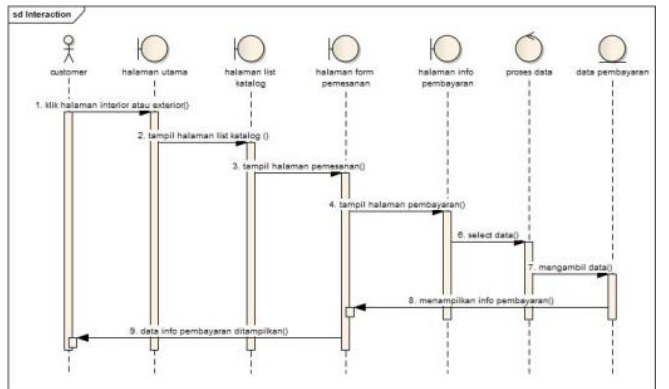

Sequence melakukan pembayaran

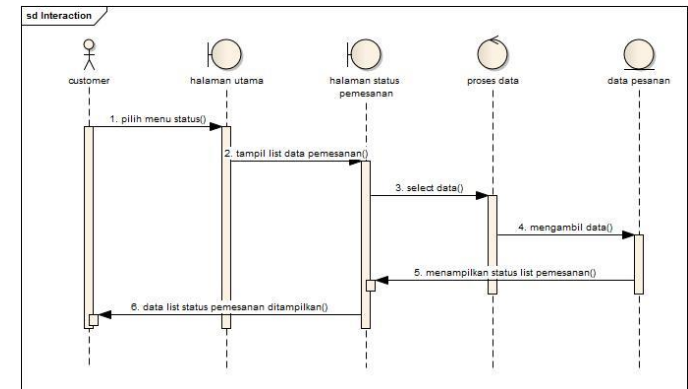

Sequence cek status pemesanan Gambar 8 Sequence diagram lanjutan

Diagram collaboration merupakan suatu diagram yang memperlihatkan dan menampilkan interaksi yang terdapat di sekitar objek-objek. Dalam diagram collaboration yang di tuliskan adalah operasi atau metode yang dijalankan antara objek dengan objek yang lain secara keseluruhan. Adapun diagram collaboration dapat dilihat pada gambar 9 .

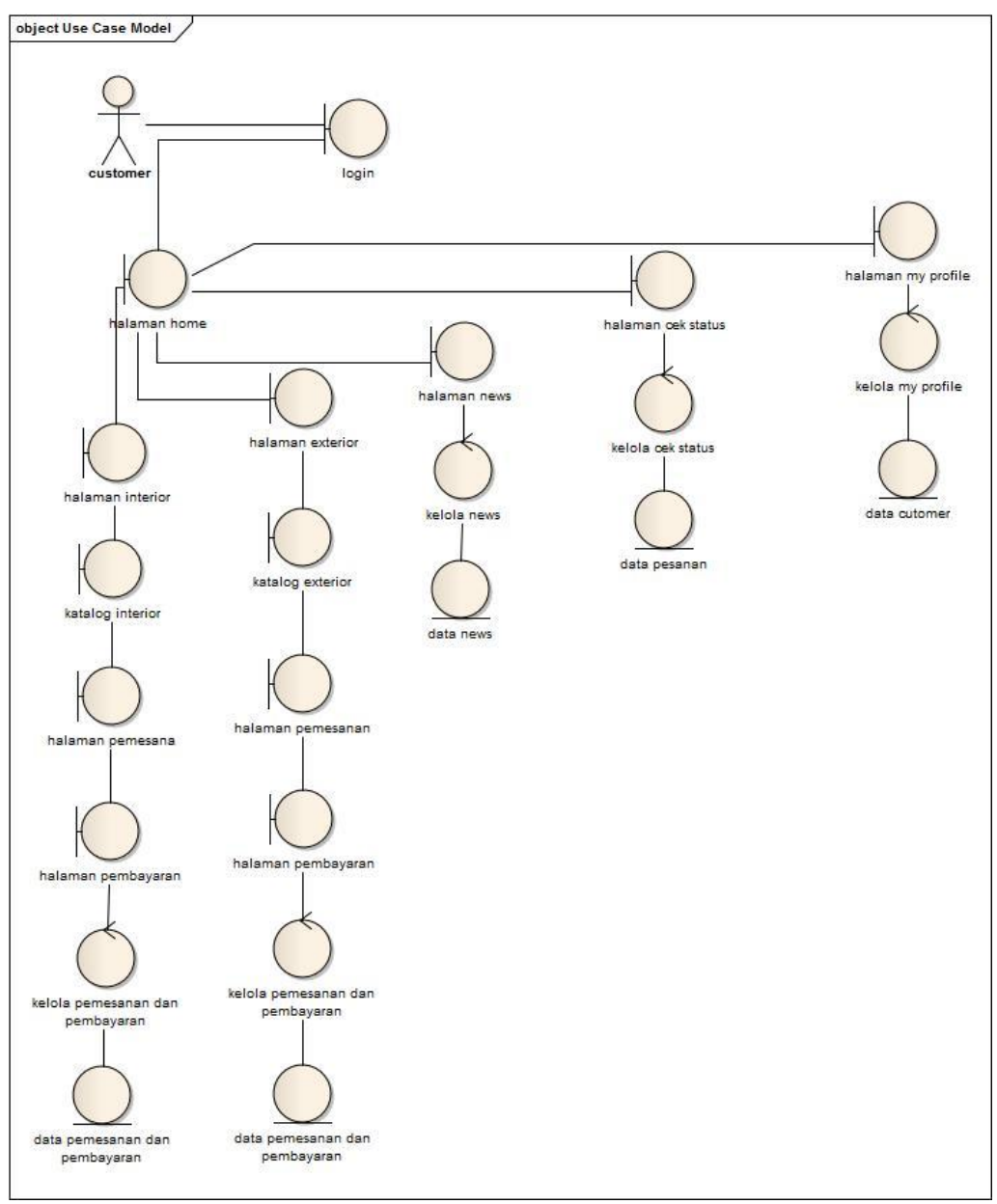

Gambar 9 Diagram collaboration 


\section{IMPLEMENTASI}

Adapun tampilan sistem yang sudah di bangun, dapat dilihat pada gambar 10 sampai gambar 13 berikut ini:

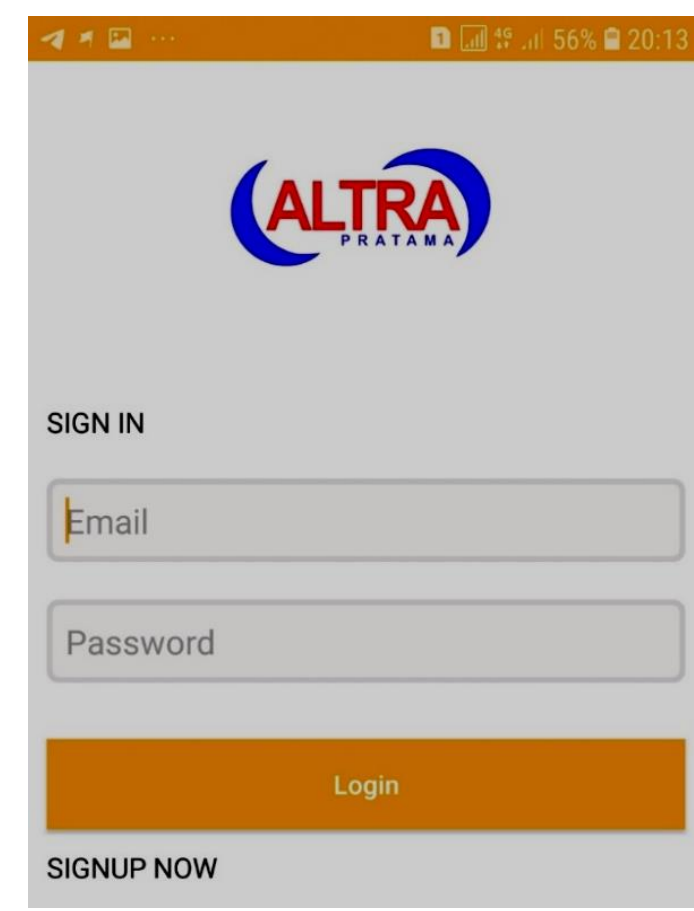

Halaman Login

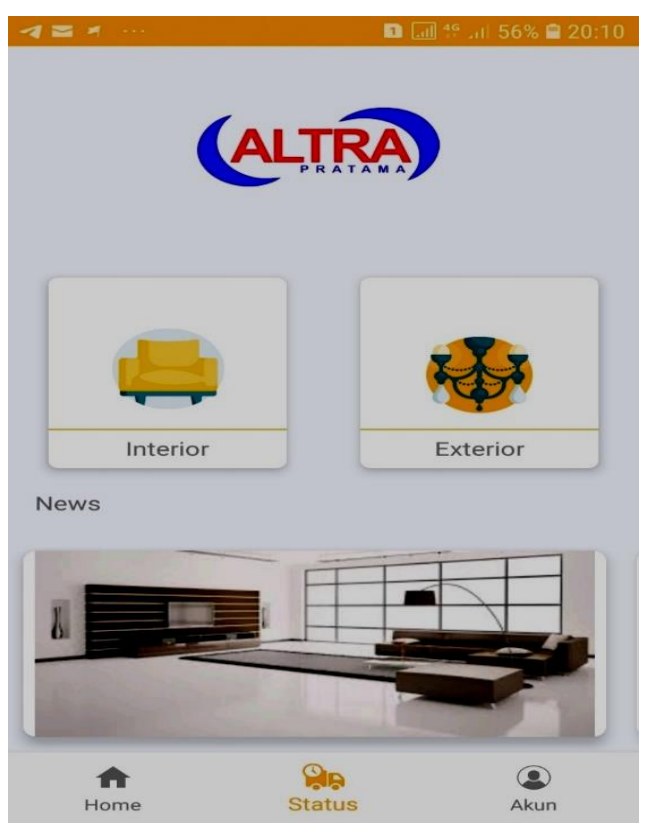

Halaman Utama

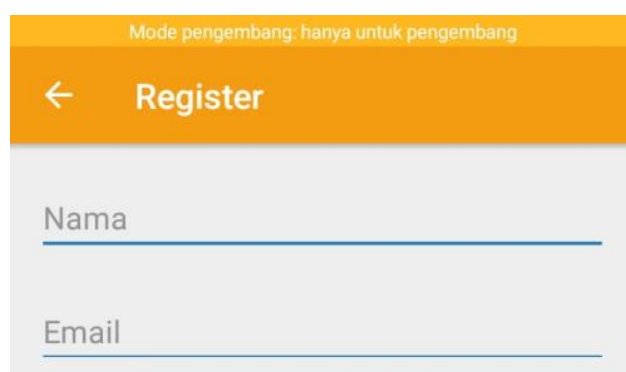

Telepon

Password

confirm Password

Register

anda sudah mendaftar? Silahkan Login

Halaman Register

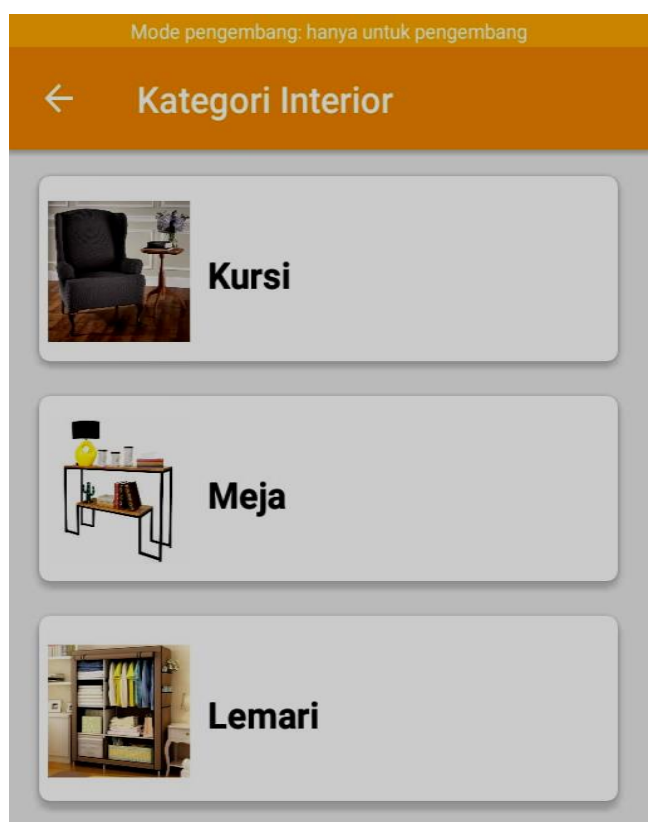

Halaman kategori Interior

Gambar 10 Hasil Implementasi Program 


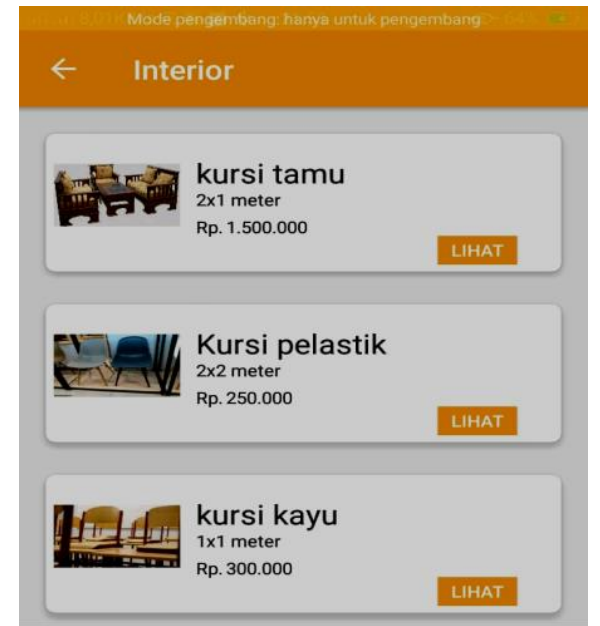

Halaman Interior

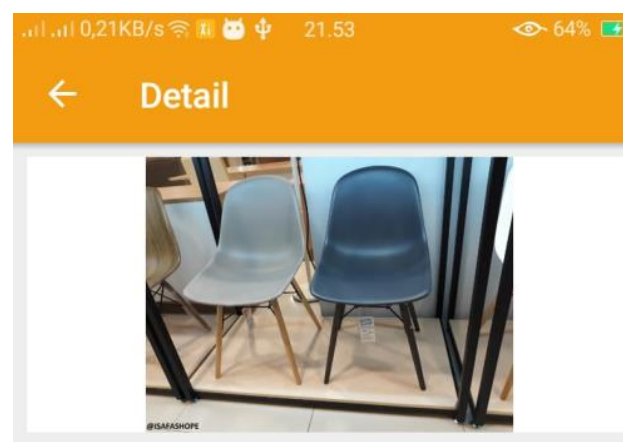

Kursi Pelastik

Rp. 250.000

deskripsi produk

Lorem Ipsum is simply dummy text of the printing and typesetting industry. Lorem Ipsum has been the industry's standard dummy text ever since the $1500 \mathrm{~s}$, when an unknown printer took a galley of type and scrambled it to make a type specimen book.

Halaman detail produk

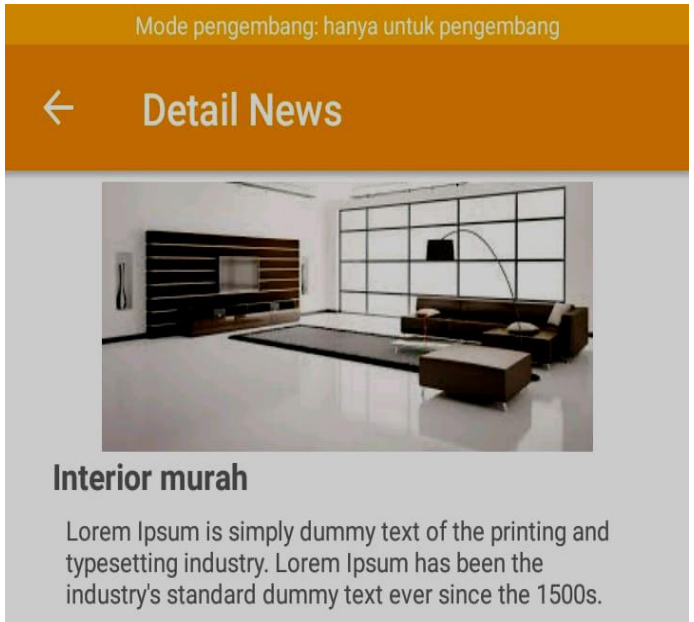

Halaman news

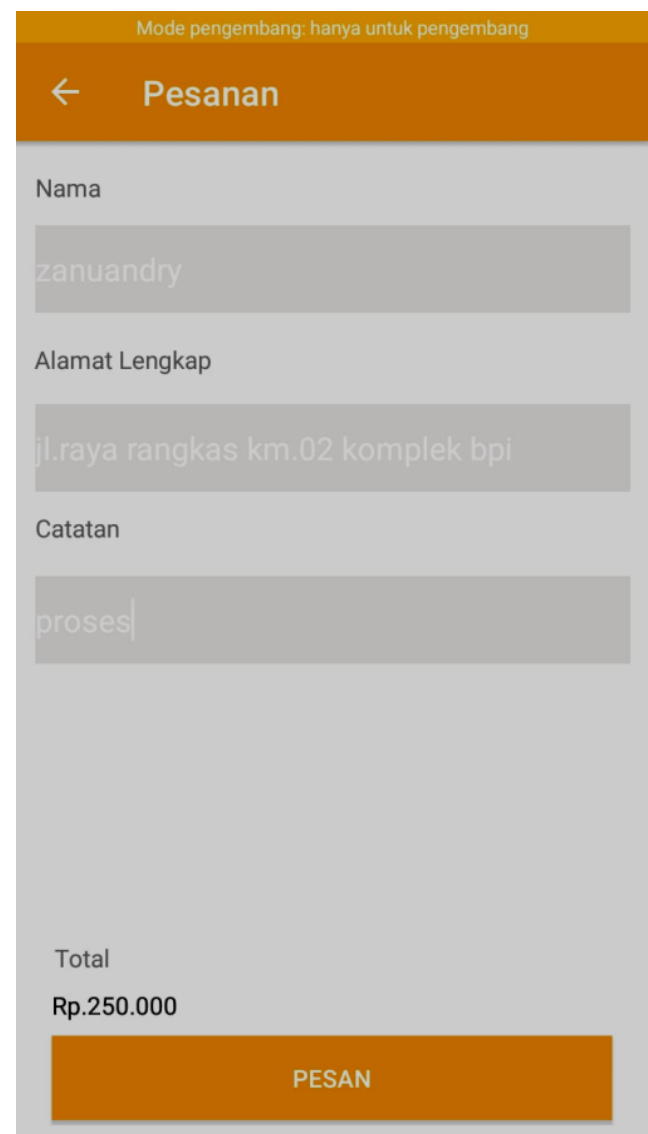

Halaman pemesanan

Gambar 11 Hasil Implementasi Program Lanjutan (1) 


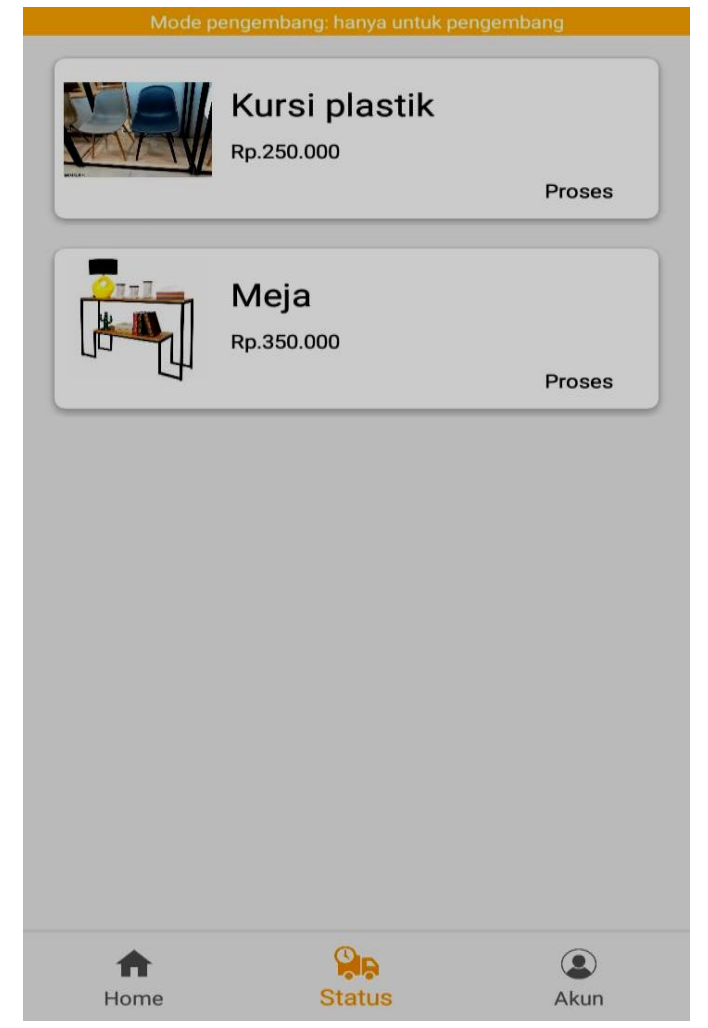

Halaman status

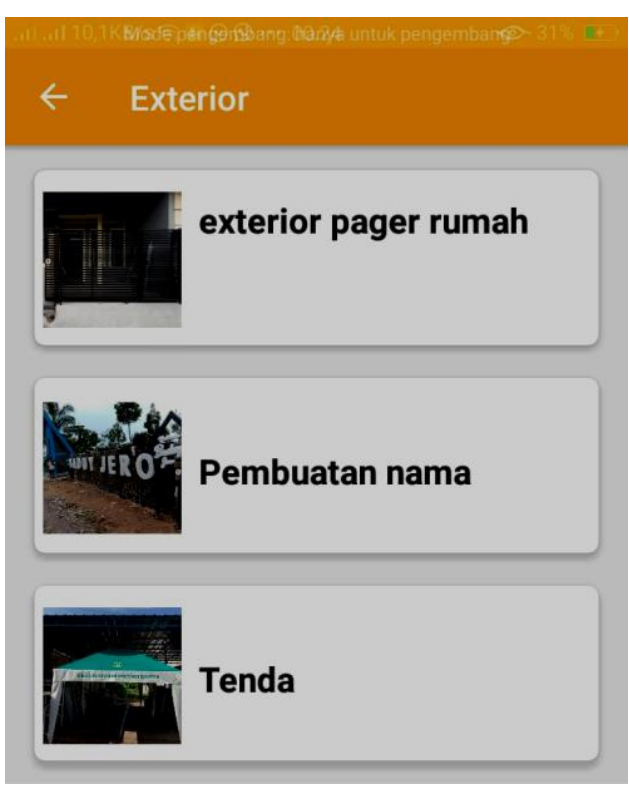

Halaman exterior

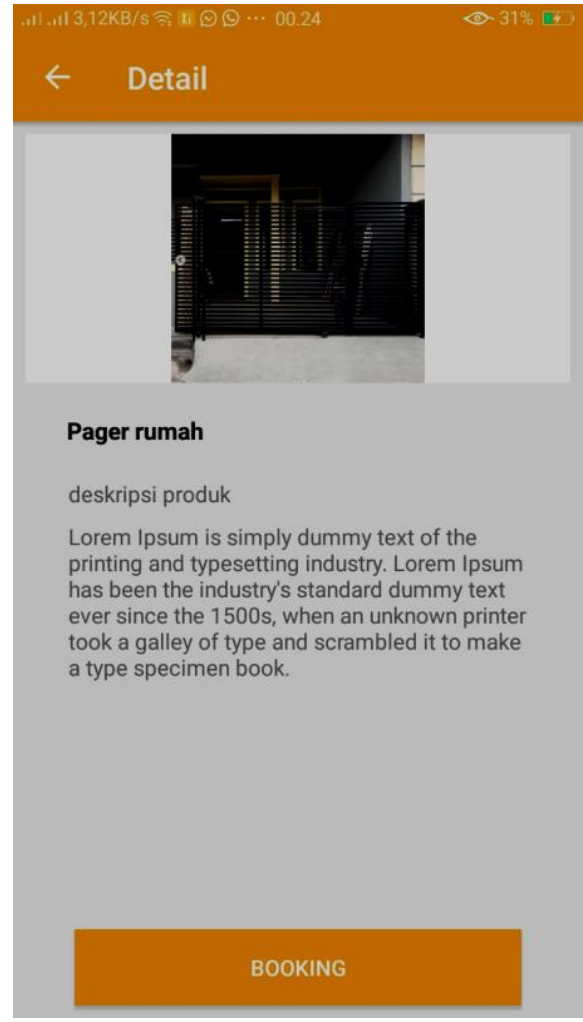

Halaman detail exterior

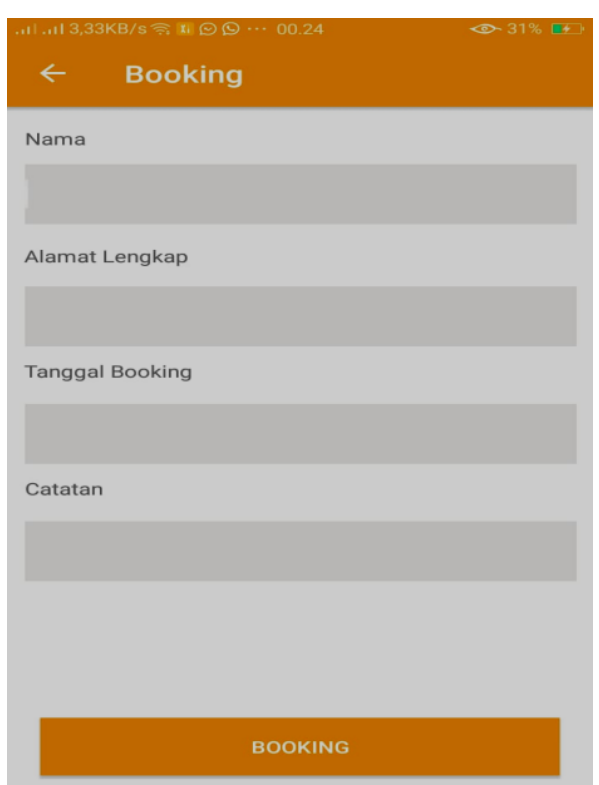

Halaman boking exterior

Gambar 12 Hasil Implementasi Program Lanjutan (2) 


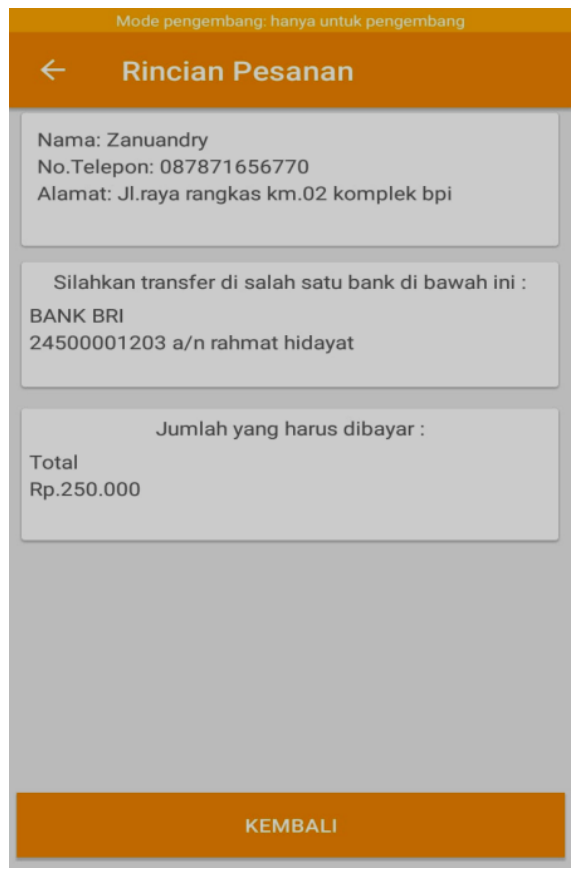

Halaman rincian pemesanan

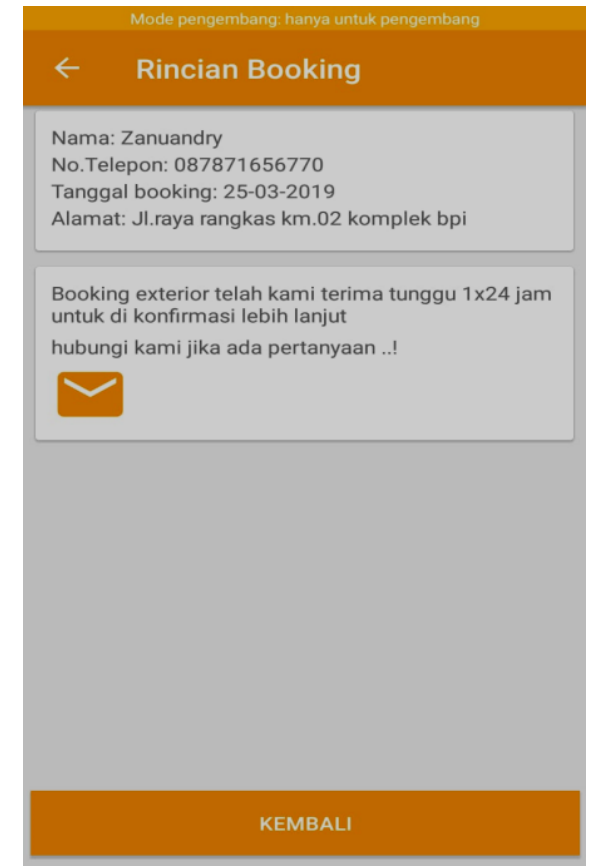

Halaman rincian boking exterior

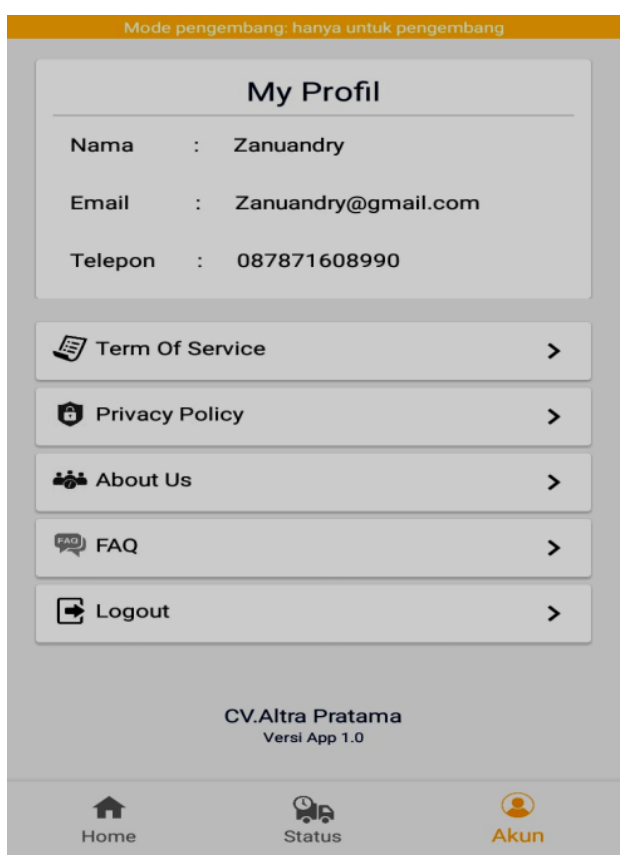

Halaman my profil

Gambar 13 Hasil Implementasi Program Lanjutan (3)

\section{KESIMPULAN}

Berdasarkan pembahasan pada analisis, desain, implementasi dan pengujian yang telah dilakukan, maka dapat ditarik kesimpulan sebagai berikut : 
1. Aplikasi penjualan online interior and exterior rumah pada CV.Altra Pratama berbasis android di bangun dengan menggunakan android studio versi 3.0.2 dan android SDK sebagai tools API, aplikasi ini dibuat dengan Bahasa pemograman Java dan XML, dengan menggunakan metode prototype.

2. Aplikasi penjualan online interior and exterior rumah pada CV.Altra Pratama berbasis android telah di bangun dengan baik sehingga konsumen bisa melakukan pemesanan melalui smartphone dengan cepat serta berkualitas.

\section{SARAN}

Saran untuk pengembangan aplikasi ordering interior and exterior ini lebih lanjutnya adalah pengembang dapat menambahkan fitur fungsi saldo menggunakan payment digital agar ketika pengisian saldo terverifikasi otomatis oleh sistem dan bekerja sama dengan pihak ketiga seperti: payment Doku dan payment Midtrans

\section{DAFTAR PUSTAKA}

Bhakti Destian Wijaya, Fenty E.M.A, A. dan Andrew Fiade (2015). Implementasi Json Parsing pada aplikasi mobile e-commerce studi kasus : cv v3 teknologi Indonesia.

Hendi Wijaya, Wellia Shinta Sari. M.Kom, (2015). Rancangan Bangun Mobile Commerce Berbasis Android pada Toko Duta Buku Semarang.

Heru Purwanto, Achmad Sumbaryadi, Sarmadi (2018). E-Crm Berbasis Web Pada Sistem Informasi Penjualan Funiture.

Mikhael Ferdika, Heri Kuswara, (2017). Sistem Informasi Penjualan Berbasis Web Pada PT Era Makmur Cahaya Damai Bekasi.

M. Qomaruddin, Adjat Sudradjat, Robi Suandi (2018). Sistem Informasi Penjualan Batik Berbasis Web Pada Toko IOS Pasar Grosir Setono.

Nia Canitai, Ahmad Lubis Gozali, A. Sumarudin (2017). Implementasi Sistem Informasi Pemesanan Menu Makanan Dan Minuman Pada Kafe Berbasis Web Menggunakan Jaringan Intranet.

Rizal Majid, Ahmad Riyadi, Seitan Wardani. M.Kom, (2017). Sistem Informasi Pemesanan Desain Interior Dan Exterior Rumah Berbasis Web Studi Kasus Di Cv. Graha Anggun Abadi Yogyakarta. 